\title{
Childhood obesity: Pharmacokinetic considerations for drugs used in the intensive care unit
}

\author{
Alejandro Donoso F., M.D. ${ }^{a}$, Daniela Ulloa V., Kinesiologist ${ }^{a}$, \\ Dina Contreras E., Kinesiologist ${ }^{a}$ and Daniela Arriagada S., M.D. ${ }^{a}$
}

\begin{abstract}
An adequate drug dosage at treatment initiation is particularly relevant for critically ill patients. An inadequate dosage may result in therapeutic failure, potentially severe adverse events, and unnecessary health expenditures.

At present, due to the higher incidence of childhood obesity, primary care physicians are more commonly faced with this population, so they need to make appropriate therapeutic decisions. Knowledge of the resulting pharmacokineticalterations caused by increased body fat is critical. The optimal drug dosage is not completely defined and the correct body descriptor should be used, although there is no consensus on which is the most adequate one. The objective of this update is to gain insight on pharmacokinetic alterations that affect dosage in the critically ill obese pediatric patient and, specifically, those related to the drugs most commonly used in this population during their stay in the pediatric intensive care unit.

Key words: obesity, critical care, pharmacokinetics, dosage, body weight.
\end{abstract}

http: / / dx.doi.org/ 10.5546/ aap.2019.eng.e121

To cite: Donoso F A, Ulloa V D, Contreras E D Arriagada S D. Childhood obesity: Pharmacokinetic considerations for drugs used in the intensive care unit. Arch Argent Pediatr 2019;117(2):e121-e130.

\section{INTRODUCTION}

Childhood obesity is a worldwide

a. Unit of Pediatric Critical Patients, Hospital Clínico Metropolitano

La Florida, Santiago, Chile.

\section{E-mail address:}

Alejandro Donoso F., M.D.: adonosofuentes@ gmail.com

\section{Funding:}

None.

Conflict of interest: None

Received: 1-2-2018

Accepted: 9-11-2018 should be taken into consideration to minimize toxicity and prevent subtherapeutic levels. ${ }^{10}$ However, there is still no consensus in relation to the adequate dosage to be used for different conditions. ${ }^{10,11}$

The effects of obesity on drug dosage in the adult population are well documented. ${ }^{12-14}$ However, the pharmacokinetic assessment of drugs used in children is more limited, especially in the case of obese patients and, moreover, if they are critically ill. ${ }^{15}$

Drug dosage in pediatrics is based on the changes occurred during normal growth and development, such as protein binding, body water, fat mass, cytochrome P450 (CYP450) enzymatic ability, and functional maturity of the kidney. ${ }^{10,11}$

Obese patients have a larger amount of fat body mass and lean body mass ${ }^{16}$ and a higher proportion of extracellular water compared to total body water. ${ }^{17}$ In addition, an increased blood volume, cardiac output, ${ }^{18}$ and renal blood flow have also been described in obese adults. ${ }^{19}$ These alterations may alter pharmacokinetic parameters, such as drug absorption, volume of distribution ( $\mathrm{Vd})$, and clearance ${ }^{14}$ thus generating significant consequences on obese children. ${ }^{6,20}$

The objective of this update is to gain insight on pharmacokinetic alterations that affect dosage in the critically ill obese pediatric patient and, specifically, those related to the drugs most commonly used in this population during their stay in the pediatric intensive care unit (PICU).

Patients younger than 2 years old were excluded from these recommendations due to the pathophysiological characteristics typical of obesity in this age group. 


\section{Pharmacokinetic alterations}

Given the prevalence of childhood obesity, as well as its impact on public health, it is concerning that there are few recommendations in relation to drug dosage in this population. ${ }^{10,11,21-23}$ Available data correspond to case reports and retrospective cohort studies; most included a small number of cases. Besides, data sheets usually do not point out specific recommendations.

Few systematic reviews have been done to assess pharmacokinetics and dosage in obese children, and they concluded that more information is required to establish a safe and effective dosage in this population. . $^{15,24,25}$

The extrapolation of results based on studies conducted in the adult population has proven inaccurate to predict pharmacokinetic parameters in children due to the differences in body composition, enzymatic activity and expression maturity, and the various metabolic pathways. ${ }^{12,26}$ In addition, a large number of pharmacokinetic studies are done in patients who are not critically ill, so results should be analyzed with caution.

Obese patients have several physiological characteristics that may cause alterations in drug absorption (studied only in adults), distribution, and metabolism. ${ }^{27,28}$ Likewise, they have shown increased body volume, total water content, fat body mass, lean body mass, and bone mineral density compared to non-obese children of the same age, height, and sex. ${ }^{16}$ In addition, lean body mass is more hydrated in obese children, as a result of an increase in extracellular water. ${ }^{16,29}$

$\mathrm{Vd}$ and clearance are the determining primary pharmacokinetic outcome measures to be considered when prescribing a systemic drug. ${ }^{30}$ $\mathrm{Vd}(\mathrm{L} / \mathrm{kg})$ is a theoretical parameter correlated to the total amount of drug distributed in the body and the resulting plasma level, which determines the loading dose.

$\mathrm{Vd}$ is a parameter specific to each individual and may vary in physiological (age, sex) and pathological (shock) conditions. It is the outcome measure that is most affected by obesity ${ }^{13}$ and is mostly determined by the physicochemical properties of the drug (lipid partition coefficient and plasma protein binding). Highly lipophilic drugs distribute extensively into adipose tissue and, therefore, have a high $\mathrm{Vd}$. Because of this, dosage should be estimated based on total body weight and would potentially require increasing drug dosage. Conversely, hydrophilic drugs should be dosed based on ideal body weight (IBW) because they remain in the intravascular space and bind, to a lesser extent, to adipose tissue, thus generating a lower $\mathrm{Vd}$ and a potential risk for overdose. ${ }^{24}$

Clearance $(\mathrm{mL} / \mathrm{min}$ or $\mathrm{L} / \mathrm{h})$ is necessary to estimate the maintenance dose required to achieve an effective drug plasma level and is regulated by metabolic and organ perfusion capacity, mainly in the liver and kidneys, which excretes the drug continuously, proportionally and in a plasma level-dependent manner (first order or linear kinetics).

This way, in obese children, $\mathrm{Vd}$ and clearance are better represented by total body weight (TBW) and lean body weight (LBW), respectively. ${ }^{31,32}$

Therefore, some drugs may be administered in a supra- or infratherapeutic dose, depending on the body descriptor used, leading to drug toxicity ${ }^{33}$ or therapy failure. ${ }^{34,35}$ Recently, in a retrospective cohort study, Burke et al. ${ }^{36}$ reported that obese children received anesthetic agents at non-recommended doses. Likewise, the use of potentially harmful doses during cardiopulmonary resuscitation, ${ }^{37}$ which leads to a worse vital prognosis, ${ }^{35}$ has been described.

Obesity is also associated with a significant increase in subcutaneous adipose tissue, and this may potentially interfere with transdermal, subcutaneous or intramuscular drug absorption. However, most published studies conducted in the adult population reported that absorption in obese and normal weight patients is similar. ${ }^{14}$

The effect of obesity on plasma lipid or protein binding of several drugs is uncertain..$^{28,38}$ Obesity does not change serum albumin levels but the increase in triglyceride, lipoprotein, cholesterol, and free fatty acid levels may affect drug affinity with serum proteins and increase their free plasma level..$^{39}$

Changes in the liver may alter drug metabolism and clearance. Fatty infiltration and non-alcoholic steatohepatitis are very frequent in obese patients, ${ }^{40}$ especially in adults with morbid obesity. ${ }^{41,42}$ These conditions may alter functional morphology and, secondarily, modify liver blood flow, ${ }^{43}$ which affects clearance. The effect of an altered liver blood flow on drug metabolism in obese children is not clear yet. In addition, the outcomes of studies about the effect of obesity on CYP450 function and expression are not conclusive, except for CYP3A4 (primary responsible for phase I metabolic pathway) and CYP2E1, whose function and expression have been described to increase and reduce, respectively. ${ }^{44}$ However, currently there is no experimental evidence that demonstrates 
the impact of obesity-induced liver damage on clearance.

The effects of obesity on renal function, ${ }^{45}$ and therefore, drug excretion, are still under discussion, especially in the pediatric population. ${ }^{46}$ An increase in kidney size, blood flow, and glomerular filtration rate has been described in obese patients. ${ }^{19,47}$ These factors may modify the dosing frequency of drugs excreted by the kidneys in order to achieve a specific therapeutic level. ${ }^{11,28}$ Available evidence indicates a greater use of LBW in the Cockcroft-Gault formula to estimate creatinine clearance in obese patients. ${ }^{48,49}$ However, there are no validated formulas to estimate the glomerular filtration rate in pediatric patients. ${ }^{11}$

Table 1 shows the physiological and body composition changes in obese patients that affect drug disposition in the body.

\section{Weight and size body descriptors}

Approximately 30-50\% of body weight in an obese subject is fat mass that is poorly vascularized. In addition, it is responsible for $75 \%$ of excess weight; the rest corresponds to lean body mass. ${ }^{10,16,22}$ The large amount of adipose tissue changes body size and the amount of total water, which may modify the pharmacokinetics of a specific drug.
In clinical practice with pediatric patients, drugs are dosed based on TBW $(\mathrm{kg})$ or body surface area $\left(B S A, \mathrm{~m}^{2}\right)$; in the latter case, the Mosteller formula (BSA $=\sqrt{ }$ height $(\mathrm{cm}) \times$ weight $(\mathrm{kg}) / 3600)^{50}$ is used, which also considers the possible presence of organ dysfunction. However, this is not valid for obese children because their body composition proportions are different from those of normal weight children. Therefore, these changes should be taken into consideration, ${ }^{51}$ but they are difficult to estimate through indirect measures.

Size and body mass indirect measures use the patient's weight and height and include body mass index (BMI), BSA, IBW, LBW, TBW, and adjusted body weight (ABW). All of these measures have clinical application; however, they have limitations because they do not correlate accurately to body fat percentage in children.

As pointed out before, obese children have more lean body mass and absolute fat mass, but their percentage of lean tissue per TBW kilogram is lower, whereas the percentage of fat tissue is higher.

\section{General body size equations}

BMI: it is determined by TBW divided by the square of the height in meters $\left(\mathrm{kg} / \mathrm{m}^{2}\right)$. It correlates adequately to the relative proportions of adipose tissue in children and adolescents. ${ }^{52}$

TABLE 1. Physiological changes in the obese population and their effects on pharmacokinetics

\begin{tabular}{lcc}
\hline & Expected physiological change & Pharmacokinetic parameter \\
\hline $\begin{array}{l}\text { Body composition } \\
\text { Fat per kg }\end{array}$ & Increases & $\mathrm{Vd}$ \\
$\begin{array}{l}\text { Fat-free mass, fat tissue, and mineral content } \\
\text { Lean tissue }\end{array}$ & Increases & $\mathrm{Vd}$ \\
Proportion of extracellular water & Increases & $\mathrm{Vd}$ \\
Cardiovascular & Increases & $\mathrm{Vd}$ \\
Blood volume & & $\mathrm{Vd}$ \\
Cardiac output & Increases & $\mathrm{Vd}$ \\
Plasma proteins & Increases & $\mathrm{Vd}$ \\
Plasma lipids & No change & Vd \\
Hepatic & Increases & Hepatic clearance \\
Liver blood flow & & Hepatic clearance \\
CYP activity & No change & Bioavailability \\
Gastrointestinal & Not conclusive & Bioavailability \\
Gastric emptying & & Renal clearance \\
Intestinal blood flow & Increases & Renal clearance \\
Renal & Increases & Renal clearance \\
Kidney size & & Increases \\
Glomerular filtration rate & Not conclusive &
\end{tabular}

CYP: cytochrome; Vd: volume of distribution. 
BSA: there is a non-linear relation between weight and glomerular filtration rate, cardiac output, and drug metabolism..$^{53}$ However, it makes no distinction between adipose tissue and lean tissue. It is usually used to dose fluid therapy and chemotherapeutic agents. The Mosteller formula is the most common in hospital practice. ${ }^{50}$

\section{Body mass equations}

IBW: it is defined as the desirable body weight for a specific age and height. It cannot be measured directly. There are different methods to estimate it in children: the McLaren method, ${ }^{54}$ the Moore method, ${ }^{55}$ and the BMI method. ${ }^{53}$ The latter correlates to body fat measures and can be used to estimate IBW in patients aged 2-20 years; at present, it is the recommended method to estimate IBW..$^{56}$ Recently, Callaghan and Walker developed an alignment chart to estimate it. ${ }^{57}$ If the patient's IBW is more than $40 \mathrm{~kg}$, the dose established for the adult population should be used.

LBW: it is similar to the concept of fat-free mass (sum of vital organs, extracellular fluid, muscles and bones), but it also includes the fat accumulated in cell membranes, the bone marrow, and the nervous system. Obese children have excess lean body mass, particularly in the lower limbs. It has been pointed out that, in average, $30 \%$ of excess weight in obese children corresponds to lean tissue. ${ }^{58,59}$ This may be estimated in children older than 5 years in an easy and quick manner; however, its use is not validated..$^{57}$

ABW: it reflects lean body mass plus excess fat mass determined by a cofactor $[A B W=I B W$ + cofactor (TBW - IBW)]. This descriptor is used to dose drugs with partial distribution in adipose tissue. ${ }^{21}$ In the pediatric population, it is used infrequently. ${ }^{60}$

To sum up, the body descriptor selection should consider drug lipophilicity and dose type (loading or maintenance) (Table 2).
The body descriptors used in pharmacokinetic studies and clinical practice are summarized in Table 3.

\section{PHARMACOKINETICS}

Below we describe the most relevant pharmacokinetic considerations for some of the drugs most commonly used in the intensive care unit (ICU).$^{61}$ Others are exclusively mentioned in Table 4.

\section{Benzodiazepines}

Benzodiazepines are highly lipophilic drugs. Several studies have demonstrated that both their $\mathrm{Vd}$ and elimination half-life are increased. ${ }^{27,62,63}$ Thus, when using a single intravenous benzodiazepine dose, it should be adjusted based on TBW. ${ }^{63,64}$ However, given its distribution profile, it may reach high levels rapidly, so the recommendation is to use mini loading doses due to the risk for dose-dependent respiratory depression. On the contrary, if administered in a continuous infusion, the dose should be adjusted based on IBW because its total clearance is not affected by body weight.

In relation to the pharmacokinetic profile of midazolam in obese adolescents, Van Rongen et al. ${ }^{65}$ suggested that the maintenance dose should be established at a fixed rate $(\mathrm{mg} / \mathrm{h})$ instead of at $\mathrm{mg} / \mathrm{kg} / \mathrm{h}$.

\section{Opioids}

The opioids most commonly used in the ICU are morphine (hydrophilic molecule) and phentanile (lipophilic opioid derived from phenylpiperidine). In the case of morphine, the initial dosage should be adjusted by the IBW and with titration of the desirable effect. ${ }^{21,59,66,67}$

Phentanile, due to its short half-life, allows for an easier titration and its use as continuous infusion. The use of ABW may help to prevent the potential accumulation due to its high lipophilicity. ${ }^{21,68}$ In a publication by Shibutani

TABLE 2. Body descriptor to be used based on pharmacokinetics and dose type

\begin{tabular}{lcc}
\hline Degree of lipophilicity & $\begin{array}{c}\text { Body descriptor used for } \\
\text { the loading dose }\end{array}$ & $\begin{array}{c}\text { Body descriptor used for } \\
\text { the maintenance dose }\end{array}$ \\
\hline Lipophilic drug & $\begin{array}{c}\text { Total body weight } \\
\text { Partially lipophilic drug } \\
\text { Adjusted body weight } \\
\text { Ideal body weight }\end{array}$ & $\begin{array}{c}\text { Lean body weight } \\
\text { Lean body weight }\end{array}$ \\
\hline
\end{tabular}

* To prevent the risk for toxicity, ideal body weight should be used. 
TABLE 3. Body size descriptors and body mass

\begin{tabular}{|c|c|c|c|}
\hline $\begin{array}{l}\text { Body mass and } \\
\text { body size descriptors }\end{array}$ & Population & Formula & Application \\
\hline Term & & Definition & \\
\hline TBW & & Patient's current weight in kilograms & $\begin{array}{l}\text { Used to establish dosage in } \\
\text { the pediatric population. }\end{array}$ \\
\hline BMI & $\begin{array}{l}\text { Older than } \\
2 \text { years old }\end{array}$ & TBW $(\mathrm{kg})$ divided by height ${ }^{2}(\mathrm{~m})$ & $\begin{array}{l}\text { Used to categorize the degree of } \\
\text { obesity. Rarely used to establish } \\
\text { drug dosage. }\end{array}$ \\
\hline IBW in adults & & $\begin{array}{c}\text { Man: } 49.9 \mathrm{~kg}+0.89 \times(\text { height in } \mathrm{cm}-152.4) \\
\text { Woman: } 45.4 \mathrm{~kg}+0.89 \times(\text { height in } \mathrm{cm}-152.4)\end{array}$ & Considers sex difference. \\
\hline IBW in children* & $\begin{array}{l}\text { Older than } \\
2 \text { years old }\end{array}$ & $\begin{array}{l}\text { Desirable weight for a specific height and age. } \\
\text { It corresponds to the P50 of } \\
\text { BMI for age } x \text { height }{ }^{2}(\mathrm{~cm})\end{array}$ & $\begin{array}{l}\text { Suggested for hydrophilic drugs } \\
\text { and to establish the } \\
\text { maintenance dose. }\end{array}$ \\
\hline $\mathrm{BSA}(\mathrm{m} 2)^{\star *}$ & Children and adults & $\checkmark$ height $(\mathrm{cm}) \times$ weight $(\mathrm{kg}) / 3600$ & $\begin{array}{l}\text { Frequently used for chemotherapy } \\
\text { and fluid therapy. }\end{array}$ \\
\hline ABW & Mainly adults & $\begin{array}{c}\text { IBW }+ \text { drug factor } x(\text { TBW }- \text { IBW }) \\
\text { Usual factor } 0.3-0.4\end{array}$ & $\begin{array}{c}\text { Suggested for } \\
\text { aminoglycoside dosage. }\end{array}$ \\
\hline LBW & & $\begin{array}{c}\text { TBW - fat weight Child: IBW + } 0.29(\mathrm{TBW}-\mathrm{IBW}) \\
\text { Man: } 1.10 \times \mathrm{TBW}-0.0128 \times \mathrm{BMI} \times \mathrm{TBW} \\
\text { Woman: } 1.07 \times \mathrm{TBW}-0.0148 \times \mathrm{BMI} \times \mathrm{TBW}\end{array}$ & Considers sex difference. \\
\hline
\end{tabular}

$t^{*}$ As per the BMI method. ** As per the Mosteller formula (N Engl J Med. 1987;317:1098).

TBW: total body weight; IBW: ideal body weight; ABW: adjusted body weight; BSA: body surface area; BMI: body mass index.

TABLE 4. Recommended drug dose as per the body descriptor used for obese children ${ }^{11,12,22,34,36}$

\begin{tabular}{|c|c|c|}
\hline Drug & Body descriptor & Remarks \\
\hline $\begin{array}{l}\text { Antiviral agents } \\
\text { Acyclovir }\end{array}$ & IBW & Maximum dose in adults $10 \mathrm{mg} / \mathrm{kg} /$ dose every 8 hours \\
\hline $\begin{array}{l}\text { Antifungal agents } \\
\text { Voriconazole }\end{array}$ & & Maximum dose in adults $300 \mathrm{mg} /$ dose \\
\hline $\begin{array}{l}\text { Antibiotics } \\
\text { Amikacin }\end{array}$ & ABW (factor 0.4) & $\begin{array}{l}\text { Plasma levels should be determined. } \\
\text { Maximum dose in adults } 1.5 \mathrm{~g} / \text { day }\end{array}$ \\
\hline Gentamicin & ABW (factor 0.4) & $\begin{array}{l}\text { Plasma levels should be determined. } \\
\text { Maximum dose in adults } 5-7 \mathrm{mg} / \mathrm{kg} / \text { day, max. } 480 \mathrm{mg} / \text { day }\end{array}$ \\
\hline Clindamycin & TBW & Maximum dose in adults $2.7 \mathrm{~g} /$ day \\
\hline Cephalosporins & TBW & $\begin{array}{c}\text { Maximum dose in adults } \\
\text { Ceftriaxone: } 4 \mathrm{~g} / \text { day } \\
\text { Cefotaxime: } 12 \mathrm{~g} / \text { day } \\
\text { Ceftazidime: } 9 \mathrm{~g} / \text { day } \\
\text { Cefazoline: } 8-12^{*} \mathrm{~g} / \text { day } \\
\text { * Life-threatening infections }\end{array}$ \\
\hline Linezolid & & $\begin{array}{l}\text { Standard dose } 600 \mathrm{mg} / 12 \text { hours } \\
\text { Maximum dose in adults } 1.2 \mathrm{~g} / \text { day }\end{array}$ \\
\hline Meropenem & TBW & $\begin{array}{l}\text { Increased distribution in obese patients. } \\
\text { Maximum dose in adults } 6 \mathrm{~g} / \text { day }(9 \mathrm{~g} / \text { day in the case of meningitis) }\end{array}$ \\
\hline Metronidazole & TBW & Maximum dose in adults $2.0 \mathrm{~g} /$ day \\
\hline Piperacillin/tazobactam & TBW & Maximum dose in adults $16 \mathrm{~g} /$ day \\
\hline $\begin{array}{l}\text { Quinolones } \\
\text { (ciprofloxacin) }\end{array}$ & $\begin{array}{c}\text { TBW } \\
\text { ABW (factor 0.4) }\end{array}$ & $\begin{array}{l}\text { Some authors recommend using TBW } \\
\text { in case a sufficient dose is not achieved. } \\
\text { Maximum dose in adults } 1.2 \mathrm{~g} / \text { day }\end{array}$ \\
\hline Vancomycin & $\begin{array}{l}\text { TBW } \\
\text { ag and maintenance doses) }\end{array}$ & $\begin{array}{l}\text { The recommendation assumes a normal kidney function. } \\
\text { Plasma levels should be determined. } \\
\text { Maximum dose in adults } 4 \mathrm{~g} \text { / day }\end{array}$ \\
\hline
\end{tabular}




\section{Anticonvulsant agents \\ Valproic acid}

TBW

Carbamazepine IBW (loading and maintenance doses)

Phenytoin ABW (loading dose)

IBW (maintenance dose) or fixed dose at $300 \mathrm{mg} /$ day

Phenobarbital

TBW

Levetiracetam

ABW

Benzodiazepines

TBW (loading dose)

(diazepam, lorazepam, IBW (maintenance dose)

midazolam)

Inotropes and vasoactive agents

Adrenaline

TBW

IBW

Catecholamines

(dopamine, dobutamine)

Milrinone

TBW

Sodium nitroprusside

TBW

\section{Anesthetic agents}

Dexmedetomidine

Phentanile IBW

Ketamine IBW

$\begin{array}{ll}\text { Methadone } & \text { IBW } \\ \text { Morphine } & \text { IBW }\end{array}$

Propofol IBW (loading dose) TBW (maintenance dose)

Rocuronium

ABW

Vecuronium IBW

Anticoagulants

Enoxaparin

TBW

Heparin
Prophylaxis with standard dose 5000-7500 U 3 times/day Treatment of deep vein thrombosis and TBW
Wide therapeutic range and drug level monitoring.

Maximum dose in adults. Loading dose: $800 \mathrm{mg}$ Maintenance dose: $30 \mathrm{mg} / \mathrm{kg} /$ day Drug levels should be monitored. Plasma levels should be determined. Maximum dose in adults $2 \mathrm{~g}$ Drug levels should be monitored.

Volume of distribution similar to total body water. Maximum dose in adults. Loading dose: $2.5 \mathrm{~g}$ Clinical monitoring is necessary.
Small volume of distribution Maximum dose in adults $1 \mathrm{mg} /$ dose

Titrate to achieve the effect. Rapid initiation and short half-life.

Hydrophilic drug with a small therapeutic window. Wide titration range.

Pharmacokinetics suggest using lean body mass to estimate the dose; however, there is a risk for insufficient dose.

Obesity may be inversely related to drug response. May require higher doses.

High risk for bradycardia and other adverse events in critically ill patients.

Adjusted to $0.25^{21}$; clinical monitoring is necessary.

The use of IBW may reduce adverse events.

Maximum dose in adults (intravenous): $5 \mathrm{mg} / \mathrm{kg}$

Maintenance dose: 80-120 mg/day

Intermittent doses may be preferred over continuous infusion.

Clinical monitoring is necessary.

The dose should start at $2 \mathrm{mg} / \mathrm{kg}$

and then titration is required.

Clinical response should be assessed and dose titration is required. Kinetic values are similar in obese and normal weight patients.

If total body weight is used, doses above $30 \%$ of the standard dose may be required. A single dose should be avoided if BMI $>27 \mathrm{~kg} / \mathrm{m}^{2}$.

reduced or dosing may be started as per schedule. Adjust as per

Antidotes

Flumazenil

Naloxone

IBW

TBW

Neostigmine

ABW (cofactor 0.4)

Protamine sulfate

ABW (cofactor 0.4)

Fluids and electrolyte solutions

Fluids for

IBW or BSA

baseline requirement

Sodium bicarbonate IBW

$10 \%$ sodium chloride IBW

Vial: $1 \mathrm{~mL}=1.7 \mathrm{mEq}$

$10 \%$ potassium chloride

IBW

Vial: $1 \mathrm{~mL}=1.3 \mathrm{mEq}$

Calcium gluconate

IBW

Magnesium sulphate
IBW
Maximum dose in adults $0.2 \mathrm{mg} /$ dose (accumulated max.: $1 \mathrm{mg}$ )

Maximum dose in adults: $10 \mathrm{mg}$

Less adverse events and faster action.

The dose should be based on the heparin dose using ABW.

Small therapeutic window when used chronically.

Dose based on the patient's individual requirements, either age, weight or sodium plasma levels. Small therapeutic window.

Orally: $20 \mathrm{mEq}$ / dose. Intravenously: 200-400 mEq/ day (if $\mathrm{K}<2$ )

Electrolytes are charged ions, hydrophilic with low volumes of distribution. Small therapeutic window. 
Steroids

Dexamethasone TBW

Hydrocortisone TBW

Methylprednisolone IBW

Antiarrhythmics

Adenosine

Atropine

IBW

Amiodarone

TBW

TBW

Lidocaine

Diuretics

Furosemide

Immunosupressors

Ciclosporin

Insulin therapy

Crystalline insulin

Bronchodilators

Ipratropium

Salbutamol

Theophylline

Blood components

Blood products

Red blood cells IBW

Platelets IBW

Plasma IBW

Non-specific immunoglobulin IBW

Analgesics

Acetaminophen

IBW
IBW

TBW (loading dose), IBW (maintenance dose)

IBW

TBW

IBW (infusion)

TBW

TBW

TBW (loading dose), IBW (maintenance dose)
Pharmacokinetic profile similar to prednisone.

Maximum dose in adults 200-300 mg. $6 \mathrm{~g}$ for shock

Maximum dose in adults, pulse therapy $1 \mathrm{~g}$.

Hydrophilic drug with a small volume of distribution

Maximum dose in adults, first $6 \mathrm{mg} /$ second $12 \mathrm{mg}$

Large volume of distribution into the extravascular space.

Recommended with caution due to the potential reduced clearance in the long term.

Maximum dose in adults. Loading dose: $150 \mathrm{mg} 1.2 \mathrm{~g} /$ day

High volume of distribution in obese patients; however,

clearance is the same in obese and normal weight patients.

Risk for ototoxicity.

Maximum dose in adults $40 \mathrm{mg}$

Monitoring is required because it has a small therapeutic window. Obese children require lower maintenance doses.

Conservative initial dose to prevent hypoglycemia.

Supported by current practice.

Maximum dose in adults: Nebulization: $10 \mathrm{mg} /$ day Spray: $1.6 \mathrm{mg} /$ day

Plasma levels should be determined.

Minimum distribution into adipose tissue.

Volume of distribution decreases as adiposity increases.

Maximum dose in adults $1 \mathrm{~g} /$ dose $-4 \mathrm{~g} /$ day

TBW: body weight total; IBW: ideal body weight; ABW: adjusted body weight;

BSA: body surface area; K: potassium.

et al., ${ }^{69}$ they reported that the infusion based on TBW may lead to overdose, whereas clearance correlated to the pharmacokinetic mass (similar to LBW) and not to TBW.

However, currently, there is no precise knowledge on which is the best body descriptor to establish the dosage of opioid agonists in obese children and, since these drugs have a narrow therapeutic range, they should be used with caution.

\section{Antibiotics}

Obesity is considered a risk factor for antibiotic therapy failure; therefore, an optimal dosage should be confirmed to prevent poor infection management in critically ill obese patients. ${ }^{70}$

\section{Beta-lactam antibiotics}

Beta-lactam antibiotics are probably the most frequently prescribed antibiotics in pediatrics. Cefazoline is a water-soluble antibiotic with wide distribution; $90 \%$ of the dose is excreted unchanged in urine. Changes in the Vd and clearance have not been demonstrated, so the suggestion is to establish the dosage based on TBW (maximum dose as per the recommendations for adults). ${ }^{60}$ 


\section{Vancomycin}

Vancomycin is one of the most studied antibiotics in obese children. ${ }^{71-75}$ It is widely distributed in fluids and body tissues and is mostly excreted by glomerular filtration. Pharmacokinetic studies in adults show a strong correlation between TBW and the $\mathrm{Vd}$ and clearance. On the contrary, in the pediatric population, no differences between obese and normal weight children have been demonstrated. ${ }^{74}$

Three retrospective cohort studies conducted in the pediatric population ${ }^{71,72,75}$ concluded that obese children had higher vancomycin levels (trough level) than normal weight children at a similar dose of $\mathrm{mg} / \mathrm{kg}$ of TBW.

In children, the use of a $20 \mathrm{mg} / \mathrm{kg}$ loading dose based on TBW achieves the area under the curve (AUC)/ minimum inhibitory concentration (MIC) therapeutic goal of $>400$ in the first 12 hours of treatment. ${ }^{76}$ At present, the recommendation is to use a $60 \mathrm{mg} / \mathrm{kg} /$ day maintenance dose (divided in doses every 8 hours) adjusted by TBW accompanied by monitoring of therapeutic levels. ${ }^{74}$

For patients with severe infections, a 25$30 \mathrm{mg} / \mathrm{kg}$ initial loading dose adjusted by TBW is recommended so that trough levels are achieved rapidly $(15-20 \mathrm{mcg} / \mathrm{mL}) .77,78$

\section{CONCLUSIONS}

Currently, it is difficult to establish the pharmacokinetic differences between normal weight and obese children because there are scarce clinical trials available, so the knowledge of pharmacokinetics in obese children is still limited.

In addition, it should be considered that most drugs administered to the pediatric population are prescribed based on body size measures, such as TBW and height, assuming that they are normal for age. However, there is no consensus on which is the most appropriate body descriptor to establish drug dosage in critically ill obese children. Such adequate knowledge is a critical safety event for patients.

In addition to the selected body descriptor, obesity-associated pathophysiological disorders that may predict changes in drug pharmacokinetics and pharmacodynamics should always be taken into consideration, as well as the possible presence of organ dysfunction, drug interactions, and associated diseases.

\section{REFERENCES}

1. Ogden CL, Carroll MD, Kit BK, Flegal KM. Prevalence of childhood and adult obesity in the United States, 2011-
2012. JAMA. 2014; 311(8):806-14.

2. De Onis M, Blossner M, Borghi E. Global prevalence and trends of overweight and obesity among preschool children. Am J Clin Nutr. 2010; 92(5):1257-64.

3. Ogden CL, Carroll MD, Kit BK, Flegal KM. Prevalence of obesity and trends in body mass index among US children and adolescents, 1999-2010. JAMA. 2012; 307(5):483-90.

4. Woo JG, Zeller MH, Wilson K, Inge T. Obesity identified by discharge ICD-9 codes underestimates the true prevalence of obesity in hospitalized children. J Pediatr. 2009;154(3):32731.

5. Azhdam DB, Reyhan I, Grant-Guimaraes J, Feinstein R. Prevalence and documentation of overweight and obesity in hospitalized children and adolescents. Hosp Pediatr. 2014; 4(6):377-81.

6. Donoso A, Córdova P, Hevia P, Arriagada D. El niño obeso en la Unidad de Cuidados Intensivos. Puesta al día. Arch Argent Pediatr. 2016; 114(3):258-67.

7. Bechard LJ, Rothpletz-Puglia P, Touger-Decker R, Duggan $C$, et al. Influence of obesity on clinical outcomes in hospitalized children: a systematic review. JAMA Pediatr. 2013; 167(5):476-82.

8. Hering E, Pritsker I, Gonchar L, Pillar G. Obesity in children is associated with increased health care use. Clin Pediatr (Phila). 2009; 48(8):812-8.

9. Kuhle S, Fung C, Veugelers PJ. Medication use in normal weight and overweight children in a nationally representative sample of Canadian children. Arch Dis Child. 2012; 97(9):842-7.

10. Mulla H, Johnson TN. Dosing dilemmas in obese children. Arch Dis Childh Educ Pract Ed. 2010; 95(4):112-7.

11. Kendrick JG, Carr RR, Ensom MH. Pharmacokinetics and drug dosing in obese children.J Pediatr Pharmacol Ther. 2010; 15(2):94-109.

12. Brill MJ, Diepstraten J, van Rongen A, van Kralingen S, et al. Impact of obesity on drug metabolism and elimination in adults and children. Clin Pharmacokinet. 2012;51(5):277-304.

13. Hanley MJ, Abernethy DR, Greenblatt DJ. Effect of obesity on the pharmacokinetics of drugs in humans. Clin Pharmacokinet. 2010; 49(2):71-87.

14. Jain R, Chung SM, Jain L, Khurana M, et al. Implications of obesity for drug therapy: limitations and challenges. Clin Pharmacol Ther. 2011; 90(1):77-89.

15. Harskamp-van Ginkel MW, Hill KD, Becker KC, Testoni $\mathrm{D}$, et al. Drug Dosing and Pharmacokinetics in Children With Obesity: A Systematic Review. JAMA Pediatr. 2015; 169(7):678-85.

16. Wells JC, Fewtrell MS, Williams JE, Haroun D, et al. Body composition in normal weight, overweight, and obese children: matched case-control analyses of total and regional tissue masses, and body composition trends in relation to relative weight. Int J Obes (Lond). 2006; 30(10):1506-13.

17. Chumlea WC, Schubert CM, Sun SS, Demerath E, et al. A review of body water status and the effects of age and body fatness in children and adults. J Nutr Health Aging. 2007; 11(2):111-8.

18. Collis T, Devereux RB, Roman MJ, de Simone G, et al. Relations of stroke volume and cardiac output to body composition: the strong heart study. Circulation. 2001; 103(6):820-5.

19. Porter LE, Hollenberg NK. Obesity, salt intake, and renal perfusion in healthy humans. Hypertension. 1998; 32(1): 144-8.

20. McPhillips HA, Stille CJ, Smith D, Hecht J, et al. Potential medication dosing errors in outpatient pediatrics. J Pediatr. 2005; 147(6):761-7.

21. Ross EL, Heizer J, Mixon MA, Jorgensen J, et al. 
Development of recommendations for dosing of commonly prescribed medications in critically ill obese children. Am J Health Syst Pharm. 2015; 72(7):542-56.

22. Kendrick JG, Carr RR, Ensom MH. Pediatric Obesity: Pharmacokinetics and Implications for Drug Dosing. Clin Ther. 2015; 37(9):1897-923.

23. Matson KL, Horton ER, Capino AC; Advocacy Committee for the Pediatric Pharmacy Advocacy Group. Medication Dosage in Overweight and Obese Children. J Pediatr Pharmacol Ther. 2017; 22(1):81-3.

24. Sampson M, Cohen-Wolkowiez M, Benjamin D Jr, Capparelli E, et al. Pharmacokinetics of antimicrobials in obese children. Ga BI J. 2013; 2(2):76-81.

25. Rowe S, Siegel D, Benjamin DK Jr; Best Pharmaceuticals for Children Act Pediatric Trials Network Administrative Core Committee. Gaps in Drug Dosing for Obese Children: ASystematic Review of Commonly Prescribed Emergency Care Medications. Clin Ther. 2015; 37(9):1924-32.

26. Blouin RA, Warren GW. Pharmacokinetic considerations in obesity. J Pharm Sci. 1999; 88(1):1-7.

27. Cheymol G. Clinical pharmacokinetics of drugs in obesity. An update. Clin Pharmacokinet. 1993; 25(2):103-14.

28. Cheymol G. Effects of obesity on pharmacokinetics implications for drug therapy. Clin Pharmacokinet. 2000; 39(3):215-31.

29. Battistini N, Virgili F, Severi S, Brambilla P, et al. Relative expansion of extracellular water in obese vs. normal children. J Appl Physiol (1985). 1995; 79(1):94-6.

30. Medina-Gutiérrez A, Lugo-Goytia G. Consideraciones farmacocinéticas y farmacodinámicas en el paciente obeso mórbido. Rev Mex Anest. 2006; 9(Supl 1):S128-30.

31. Green B, Duffull SB. What is the best size descriptor to use for pharmacokinetic studies in the obese? Br J Clin Pharmacol. 2004; 58(2):119-33.

32. McLeay SC, Morrish GA, Kirkpatrick CM, Green B. The relationship between drug clearance and body size: systematic review and meta-analysis of the literature published from 2000 to 2007. Clin Pharmacokinet. 2012; 51(5):319-30.

33. Fisher DG, Schwartz PH, Davis AL. Pharmacokinetics of exogenous epinephrine in critically ill children. Criti Care Med. 1993; 21(1):111-7.

34. Medico CH, Walsh P. Pharmacotherapy in the Critically Ill Obese Patient. Crit Care Clin. 2010; 26(4):679-88.

35. Srinivasan V, Nadkarni VM, Helfaer MA, Carey SM, et al. Childhood obesity and survival after in-hospital pediatric cardiopulmonary resuscitation. Pediatrics. 2010; 125(3):e481-8.

36. Burke CN, Voepel-Lewis T, Wagner D, Lau I, et al. A retrospective description of anesthetic medication dosing in overweight and obese children. Paediatr Anaesth. 2014; 24(8):857-62.

37. Pinchevsky LE, Pesaturo KA, Smith BS, Hartman CA. Pilot comparison of three cardiopulmonary resuscitation medication dosing strategies in overweight children. $J$ Pediatr Pharmacol Ther. 2010; 15(4):282-9.

38. Rodríguez-DelgadoNE,MuñozCuevasJH.Farmacocinética del niño obeso. Rev Mex Anest. 2012; 35(Supl 1):S191-4.

39. Wasan KM, López-Berestein G. The influence of serum lipoproteins on the pharmacokinetics and pharmacodynamics of lipophilic drugs and drug carriers. Arch Med Res.1993; 24(4):395-401.

40. Angulo P. Nonalcoholic fatty liver disease. N Engl J Med. 2002; 346(16):1221-31.

41. Guzzaloni G, Grugni G, Minocci A, Moro D, et al. Liver steatosis in juvenile obesity: correlations with lipid profile, hepatic biochemical parameters and glycemic and insulinemic responses to an oral glucose tolerance test. Int
J Obes Relat Metab Disord. 2000; 24(6):772-6.

42. Moretto M, Kupski C, Mottin CC, Repetto G, et al. Hepatic steatosis in patients undergoing bariatric surgery and its relationship to body mass index and co-morbidities. Obes Surg. 2003; 13(4):622-4.

43. Ijaz S, Yang W, Winslet MC, Seifalian AM. Impairment of hepatic microcirculation in fatty liver. Microcirculation. 2003; 10(6):447-56.

44. Kotlyar M, Carson SW. Effects of obesity on the cytochrome P450 enzyme system. Int JClin Pharmacol Ther. 1999;37(1):819.

45. GuntaSS, MakRH. Is obesity a risk factor for chronic kidney disease in children? Pediatr Nephrol. 2013; 28(10):1949-56.

46. Savino A, Pelliccia P, Giannini C, de Giorgis T, et al. Implications for kidney disease in obese children and adolescents. Pediatr Nephrol. 2011; 26(5):749-58.

47. Henegar JR, Bigler SA, Henegar LK, Tyagi SC, et al. Functional and structural changes in the kidney in the early stages of obesity. J Am Soc Nephrol. 2001; 12(6):12117.

48. Demirovic JA, Pai AB, Pai MP. Estimation of creatinine clearance in morbidly obese patients. Am J Health Syst Pharm. 2009; 66(7):642-8.

49. Lim WH, Lim EEM, McDonald S. Lean body mass-adjusted Cockcroft and Gault formula improves the estimation of glomerular filtration rate in subjects with normal-range serum creatinine. Nephrology (Carlton). 2006; 11(3):250-6.

50. Mosteller RD. Simplified calculation of body-surface area. N Engl J Med. 1987; 317(17):1098.

51. Alvarez A, Brodsky J, Lemmens HJ, Morton J (eds.). Morbid obesity: perioperative management. $2^{\text {nd }}$ ed. Cambridge: University Press; 2010.

52. Maynard LM, Wisemandle W, Roche AF, Chumlea WC, et al. Childhood body composition in relation to body mass index. Pediatrics. 2001; 107(2):344-50.

53. Anderson BJ, Holford NH. Understanding dosing: children are small adults, neonates are immature children. Arch Dis Child. 2013; 98(9):737-44.

54. McLaren DS, Read WW. Classification of nutritional status in early childhood. Lancet. 1972; 2(7769):146-8.

55. Moore DJ, Durie PR, Forstner GG, Pencharz PB. The assessment of nutritional status in children. Nutr Res.1985; 5(8):797-9.

56. Phillips S, EdlbeckA, Kirby M, Goday P. Ideal body weight in children. Nutr Clin Pract. 2007; 22(2):240-5.

57. Callaghan LC, Walker JD. An aid to drug dosing safety in obese children: development of a new nomogram and comparison with existing methods for estimation of ideal body weight and lean body mass. Anaesthesia. 2015; 70(2):176-82.

58. Forbes GB, Welle SL. Lean body mass in obesity. Int J Obes. 1983; 7(2):99-107.

59. Mortensen A, Lenz K, Abildstrøm H, Lauritsen TLB. Anesthetizing the obese child. Paediatr Anaesth. 2011; 21(6):623-9.

60. Koshida R, Nakashima E, Taniguchi N, Tsuji A, et al. Prediction of the distribution volumes of cefazolin and tobramycin in obese children based on physiological and pharmacokinetic concepts. Pharm Res.1989; 6(6):486-91.

61. Johnson PN, Miller JL, Hagemann TM, Moffett BS. Assessment of inpatient admissions and top 25 medications for obese pediatric patients at two academic hospitals. Am J Health Syst Pharm. 2016; 73(16):1243-9.

62. Abernethy DR, Greenblatt DJ, Divoll M, Shader RI. Prolonged accumulation of diazepam in obesity. J Clin Pharmacol. 1983; 23(8-9):369-76.

63. Greenblatt DJ, Abernethy DR, Locniskar A, Harmatz JS, et al. Effect of age, gender and obesity on midazolam kinetics. 
Anesthesiology. 1984; 61(1):27-35.

64. Luten R, Zaritsky A. The sophistication of simplicity... optimizing emergency dosing. Acad Emerg Med. 2008; 15(5):461-5.

65. Van Rongen A, Vaughns JD, Moorthy GS, Barrett JS, et al. Population pharmacokinetics of midazolam and its metabolites in overweight and obese adolescents. Br JClin Pharmacol. 2015; 80(5):1185-96.

66. Aubrun F, Mazoit JX, Riou B. Postoperativeintravenous morphine titration. Br J Anaesth. 2012; 108(2):193-201.

67. Graves DA, Batenhorst RL, Bennett RL, Wettstein JG, et al. Morphine requirements using patient-controlled analgesia: influence of diurnal variation and morbid obesity. Clin Pharm. 1983; 2(1):49-53.

68. Shibutani K, Inchiosa MA Jr, Sawada K, Bairamian M. Pharmacokinetic mass of fentanyl for postoperative analgesia in lean and obese patients. Br J Anaesth. 2005; 95(3):377-83.

69. Shibutani K, Inchiosa MA Jr, Sawada K, Bairamian M. Accuracy of pharmacokinetic models for predicting plasma fentanyl concentrations in lean and obese surgical patients: derivation of dosing weight ("pharmacokinetic mass"). Anesthesiology. 2004; 101(3):603-13.

70. Longo C, Bartlett G, Macgibbon B, Mayo N, et al. The effect of obesity on antibiotic treatment failure: a historical cohort study. Pharmacoepidemiol Drug Saf. 2013; 22(9):970-6.

71. Miller M, Miller JL, Hagemann TM, Harrison D, et al. Vancomycin dosage in overweight and obese children. Am J Health Syst Pharm. 2011; 68(21):2062-8.
72. Heble DE Jr, McPherson C, Nelson MP, Hunstad DA. Vancomycin trough concentrations in overweight and obese children. Pharmacotherapy. 2013; 33(12):1273-7.

73. Eiland L, Sonawane K. Vancomycin Dosing in HealthyWeight, Overweight, and Obese Pediatric Patients. J Pediatr Pharmacol Ther. 2014; 19(3):182-8.

74. Le J, Capparelli EV, Wahid U, Wu YS, et al. Bayesian estimation of vancomycin pharmacokinetics in obese children: matched case-control study. Clin Ther. 2015; 37(6):1340-51.

75. Moffett BS, Kim S, Edwards MS. Vancomycin dosing in obese pediatric patients. Clin Pediatr (Phila). 2011;50(5):4426.

76. Nguyen WN, Bradley JS, Capparelli EV, Wu YS, et al. Optimal Weight-based Vancomycin Dosing in Obese Children Using Bayesian Estimation. Poster session presented: Session Pharmacologic Considerations in Special Populations. 55th Interscience Conference On Antimicrobial Agents And Chemotherapy (ICAAC); 2015 Sep 17-21; San Diego, California.

77. Rybak M, Lomaestro B, Rotschafer JC, Moellering R Jr, et al. Therapeutic monitoring of vancomycin in adult patients: $A$ consensus review of the American Society of Health-System Pharmacists, the Infectious Diseases Society of America, and the Society of Infectious Diseases Pharmacists. Am J Health Syst Pharm. 2009; 66(1):82-98.

78. Villena R, González CA, Nalegach ME, Vásquez A, et al. Monitoreo terapéutico de vancomicina intravenosa en una unidad de paciente crítico pediátrico. Rev ChilInfectol.2014; 31(3):249-53. 